\title{
The Problems of Investment in Innovations, Range of Products and Technological Re-equipment of the Construction Corporation
}

\author{
Boris Sultanovich Kasaev ${ }^{1}$, Azat Ashatovich Razakov ${ }^{2}$ \\ ${ }^{1}$ Professor of the Department of Marketing and Logistics Financial University under the Government of the Russian \\ Federation, Moscow, Russian Federation \\ ${ }^{2}$ Head of construction company "Slavic", Moscow, Russian Federation \\ Correspondence: Boris Sultanovich Kasaev, Department of Marketing and Logistics Financial University under the \\ Government of the Russian Federation, Leningrad Prospect 49, 125993 Moscow, Russian Federation. \\ Tel:7-905-791-5214.
}

Received: July 6, 2015 Accepted: July 20, 2015 Online Published: July 30, 2015

doi:10.11114/set.v2i1.992

URL: http://dx.doi.org/10.11114/set.v2i1.992

\begin{abstract}
The article considers the current state of the investment process in innovations applied to the construction companies in Russia. The subject of research: problems of investing in innovations, expansion and technological re-equipment of the construction corporation. The article covers the following topics: the study of statistical data regarding the present state of the construction sector. Object: to identify the main problems and the tendencies of development of the investment processes to provide innovations in the conditions of the transformed economy.

The work carried out processing statistical information, which allowed the state to give the quantitative characteristics of the construction sector and its role in the economic development of Russia, as well as in the formation of federal budget revenues. The study used methods of system analysis, synthesis, complex approach, comparison, modeling and other methods of cognition.

It is concluded that the presence of a wide range of indicators of the state of the economy in the sectoral and territorial aspects. A substantial increase in the state's share of investing activities in crisis and post-crisis period.

It is concluded that the gradual transition of the Russian construction industry, the path to the updated development involves restructuring algorithms to achieve growth. A key source providing this transition should be a systematic approach to innovation. In this regard, the structure of long-term socio-economic development of the Russian Federation for the period up to 2020 shall be implemented in two successive stages.
\end{abstract}

Keywords: innovations in the construction sector; Investment in innovations; construction companies; quantitative characteristics of the building complex; efficiency; management; technological re-equipment of the construction companies

\section{Introduction}

Many researchers believe that the level of development of the construction industry reflects the state of the economy of the country. The statistics, various printed sources, publications and the Internet contain a lot of contradictory information about the state of the construction market in Russia, however we can observe the general trend of discussions, such as a statement of growth of the majority of indices of the construction industry of the country, which quite often permits to apply to the present state of the construction industry in Russia such a promising term as a, for example, "construction boom".

One of the main specific features of the construction sector in Russia is that on its territory there is a large variety of climatic zones; however, in the main territories the factor of cold seasons undoubtedly dominates affecting design projects and impeding construction works. In other words, the first distinctive feature brings the idea that to build in Russia is not an easy task to complete. The dispute here is not entirely about peculiarities of the Russian economy but about rather severe climate conditions reducing the lifetime of the standard widely used building materials and forcing designers and architects to apply more complex and costly design projects. 


\section{Materials and Methods}

The construction industry in Russia is one of the most important and the largest so far judging by the volume of production.

Today, according to the data of the State Committee for Statistics (Goskomstat), 6,2\% of the population of the Russian Federation, that is 4,166 million people, is involved in the construction industry.

The construction complex of the Russian Federation today represents a set of the rather shattered independent economic entities with specific features, not managed by united or separate centers and not connected with the system purposes.

Due to insufficient development of the construction market, in the absence of normal competition when the overwhelming part of construction contracts is received bypassing tender (auctions), there is no proper regulation of operation conditions and public requirements to contractors so evident in the terms of market competition. This defines essential distinctions in price levels both regional and intra-regional, obligations of the parties and some other factors.

With respect to the production volume and the quantity of human resources involved the share of the construction industry is approximately one-tenth of national economy. The construction industry comprises about 175817 construction organizations.

Regulation processes in national economy and privatization of large state and assembly trusts led to a sharp increase in the number of small construction and assembly organizations of various forms of ownership. Along with establishment of small construction organizations the number of employees has been reduced from 4,0 million people in 1994 to 3,6 million people in 2011.

Countrywide among the construction and assembly organizations of public sector the number of people employed accounts for $10 \%$ of the total working population. The economic crisis painfully struck, i.e. the rates of development of the construction industry in 2010 were lower than in 2009. However for the first three quarters of 2011 the industry practically returned to its pre-crisis positions. The main indicators if development of Russian economy in 2012-2013 according to the Russian Statistics data and the Ministry for Economic Development of the Russian Federation are given in the Table 1.

Table 1.The main indicators of development of Russian economy

(in \% by the corresponding period of the previous year)

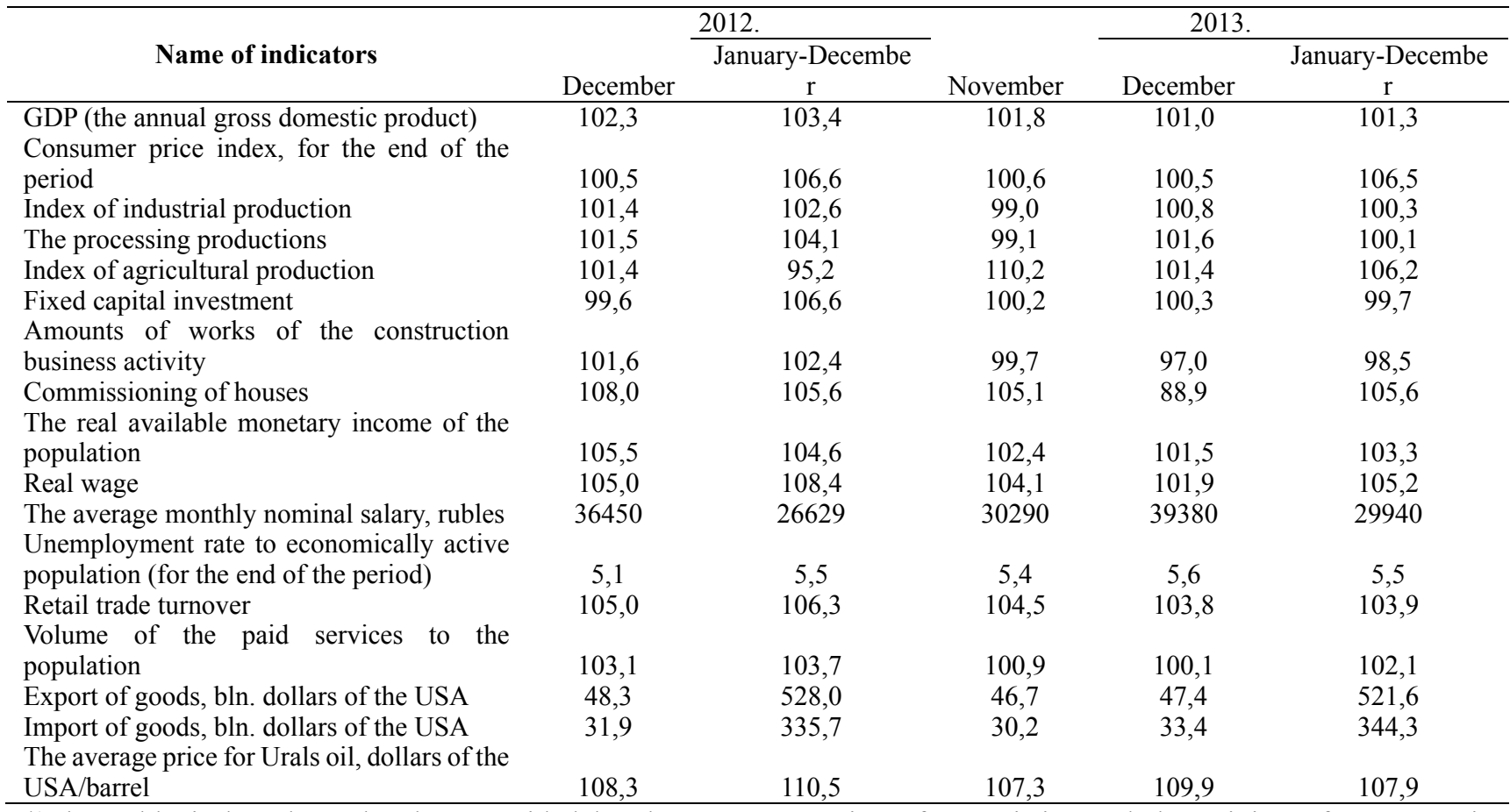

*) the Table is based on the data provided by the State Committee for Statistics and the Ministry for Economic Development of the Russian Federation.

It follows from the Table 1 that by 2013 the construction industry didn't realize the amounts of works reached in 2012, though in 2011 a certain volume growth was observed. Rehabilitation of growth in 2010 was promoted by improvement of world economy, the rising external demands and an increase in prices for raw materials of the Russian export, recovering share indexes and strengthening the position of the balance payments. In figure 1 dynamics of performance of the number of construction works for the last three years is presented. 


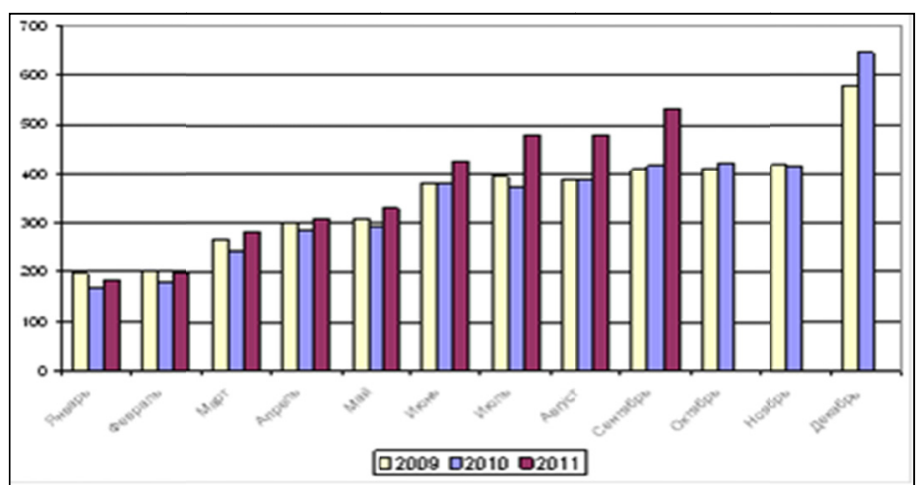

Fig. 1. Dynamics of performance of amount of works in construction industry, billion rubles (according to the Russian statistics)

As follows from the figure 1 in 2011 the amounts of construction works exceeded the amounts of works in 2009 and 2010.

Among all the projects completed during the period January-September 2011, 94,7\% of buildings are residential.

Table 2. Commissioning of buildings by their types in January-September, 2011

\begin{tabular}{lccc}
\hline \multicolumn{1}{c}{ Parameter } & $\begin{array}{c}\text { Number of buildings, } \\
\text { units }\end{array}$ & $\begin{array}{c}\text { Total structural volume of buildings, one Total area of buildings, } \\
\text { one thousand sq.m }\end{array}$ \\
\hline Buildings put into operation & 139697 & 224943,3 & 51810,5 \\
including: residential & 132240 & 164991,4 & 41660,8 \\
non-residential total: & 7457 & 59951,9 & 10149,6 \\
including: industrial & 1041 & 13388,7 & 1215,9 \\
agricultural & 880 & 7280,8 & 1435,3 \\
commercial & 2769 & 20397,9 & 3482,2 \\
administrative & 498 & 3157,1 & 764,7 \\
educational & 242 & 4165,9 & 964,3 \\
health care & 280 & 2586,3 & 580,8 \\
others & 1747 & 8975,2 & 1706,4 \\
\hline
\end{tabular}

*) the Table is based on the data provided by The State Committee for Statistics

Residential construction is considered to be the most important branch of the construction industry in the Russian Federation. Detailed information regarding construction of buildings of social cultural sector is given in the Table 3 .

Table 3.Commissioning of objects of social cultural sector

\begin{tabular}{|c|c|c|c|}
\hline \multirow{2}{*}{ Name of parameter } & \multicolumn{3}{|c|}{ January-September,January-September,January-September, } \\
\hline & 2009. & 2010. & 2011. \\
\hline Gas supply pipeline networks, one thousand $\mathrm{km}$ & 7,0 & 5,2 & 5,9 \\
\hline Heat supply system, $\mathrm{km}$ & 50,3 & 69,8 & 94,0 \\
\hline Water supply system, $\mathrm{km}$ & 584,3 & 390,9 & 733,3 \\
\hline Sewerage, $\mathrm{km}$ & 91,3 & 219,1 & 190,4 \\
\hline Hotels, one thousand beds & 4,6 & 2,6 & 3,3 \\
\hline Sanatoria, one thousand beds & 1,1 & 1,2 & 1,0 \\
\hline Recreationalt houses, guests & 661,1 & 1010,9 & 279,0 \\
\hline $\begin{array}{l}\text { Educational institutions for higher education, one thousand sq.m of } \\
\text { total area of educational and laboratory buildings }\end{array}$ & 89,8 & 112,0 & 69,8 \\
\hline Educational institutions for second-level professional education, one & & & \\
\hline $\begin{array}{l}\text { thousand sq.m of total area of educational and laboratory buildings } \\
\text { Educational institutions for primary education, one thousand students }\end{array}$ & 3,4 & 20,0 & $\begin{array}{c}10,3 \\
1,3\end{array}$ \\
\hline Secondary (high) schools, one thousand students & 35,9 & 45,4 & 32,9 \\
\hline Preschool educational institutions, one thousand pupils & 10,6 & 10,0 & 15,8 \\
\hline Medical institutions, one thousand beds & 2,7 & 3,3 & 2,5 \\
\hline $\begin{array}{l}\text { Out-patient and polyclinic establishments, one thousand visits per } \\
\text { shift }\end{array}$ & 10,4 & 11,2 & 8,4 \\
\hline $\begin{array}{l}\text { Nursing homes for elderly and disabled people (adults and children), } \\
\text { beds }\end{array}$ & 747,3 & 704,7 & 568,0 \\
\hline Cultural clubs, one thousand seats & 4,7 & 5,0 & 3,8 \\
\hline Shopping centers, one thousand sq.m of total area & 268,5 & 859,2 & 692,5 \\
\hline Business and trade centers, one thousand sq.m of total area & 183,8 & 179,1 & 117,1 \\
\hline Cult and religious buildings, units & 74,0 & 88,0 & 95,0 \\
\hline Libraries, one thousand volumes of book funds & & 2441,8 & 2742,1 \\
\hline Theaters, one thousand seats & 0,3 & 1,9 & 1,7 \\
\hline Concert and cinema and concert halls, one thousand seats & 1,2 & 2,8 & 1,8 \\
\hline
\end{tabular}


*) the Table is based on the data provided by The State Committee for Statistics

According to the State Committee for Statistics for the first 6 months of 2011 243,2 thousand apartments of the total area 20,7 million sq.m. have been put in operation. This figure is 3,7\% lower in comparison with the first 6 months of 2010.

Individual developers completed residential housing with the total area of 17,0 million sq.m, or $50,2 \%$ of the total amount of the housing built in January-September 2011.

Thus, having a closer look at the figures given in the Table 3 we can pay attention to a gain of the amounts of construction sector for cultural and social sector. In January-September 2911 the following numbers of construction projects for tourism and sport were realized: tourist and recreational centers -244 guests, stadiums $-26,3$ thousand seats, 19 swimming pools, 10 sport facilities with artificial ice rinks of the total 31,2 thousand sq.m, 53 recreational and wellbeing complexes, gyms of 49,0 thousand sq.m, winter sport slopes with the total length of 560 meters.

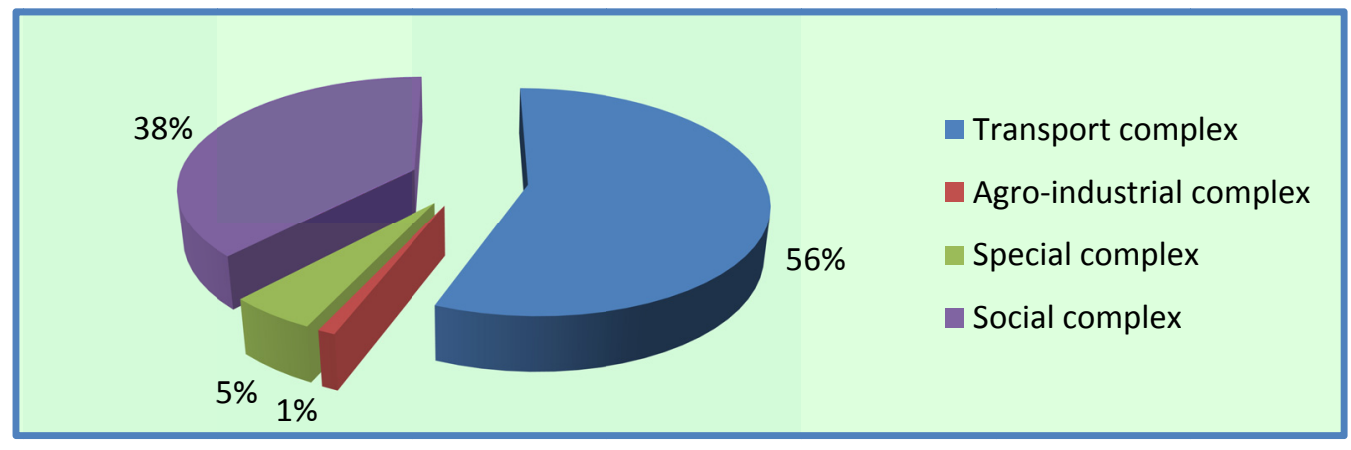

Fig. 2. Structure of financing for construction of facilities of various complexes from the federal budget in January-August, 2011, \%

According to the Federal targeted investment programme in 2011 the financing from the federal budget was provided for 3,555 thousand construction sites, it was planned to realize 2,078 thousand projects.

In January-August 2011342 billion rubles for the federal budget were allotted for financing for construction.

From the annual limit in January-September, 2011 financing in the amount of 368,3 billion rubles was allotted from the federal budget, including construction of facilities of the transport complex - 191,9 billion rubles, social complex 128,4 billion rubles, special complex - 21,3 billion rubles, agro-industrial complex - 5,7 billion rubles; from the budgets of administrative divisions of the Russian Federation and other sources - 42,2 billion rubles.

Among the factors having a negative impact on the construction companies activity are high taxation rates, high cost of building materials, constructions, products, competition among civil engineering companies.

The major factors limiting the activity of the construction companies in administrative divisions of the Russian Federation are "the high cost of building materials, constructions and projects" and "high taxation rates".

Among the factors limiting a production activity of small companies prevail "the high taxation level", "the competition between civil engineering companies", "insolvency of customers".

The cost of building materials is the most important component of the total cost of construction production.

Building materials manufactured in Russia are generally consumed on domestic market. Bituminous roofing materials, ceramic tiles, sanitary faience products, roofing slate, wood panels, timber and many other articles are exported from Russia. The average export share varies from 5 to $15 \%$. The main sales markets of the Russian manufactured goods include the countries of the former Soviet Union, and the most active buyers among them are Ukraine and Kazakhstan. In turn, it is necessary to point out that the wide range of construction and decoration materials is being imported from Ukraine to Russia.

Before crisis on the Russian market of decoration materials there was a tough competition with foreign manufacturers caused, first of all, by a difference in quality of materials. However over the past few years for such materials as ceramic tiles, linoleum, dry construction mixes, wooden floor coverings, interconnecting doors, etc., the share of import decreased more than twice.

In certain cases decrease of the import share occurred due to re-equipment of the domestic companies managed to realize investments and to increase quality of products. On the contrary in certain occasions foreign manufacturing lines just changed location - in recent years many foreign corporations have launched their plants on the territory of Russia. 
Materials of the basic general civil engineering purpose (cement, concrete, bricks, non-metallic materials, aerated concrete, precast concrete products, etc.) are being imported in insignificant quantity.

\section{Results and Discourse}

Now we will take into account some specific features of up-to-date estimates and innovative process in order to apply them to the branch examined. In the latest research projects scientists often represent the model of innovative process as a linear sequence of the following four stages: research — innovation — production - sale.

Actually the model of innovative process is much more complicated; it is conditioned on a large number of factors and generally only partially incorporates the results of scientific activity.

The innovations resulted in direct commercialization of achievements in the field of research and developments quite often have a character of radical innovations. That means the introduction into the market of absolutely new products (goods or services) with fundamentally new features.

Omitting some details and specific features of innovative activity distinguishing it from scientific activity (carrying out researches and development) the fundamental difference between both is determined: scientific activity is directed on acquiring new knowledge; innovative activity aims at obtaining commercial benefit.

According to the Center for Research and Scientific Statistics of the Ministry for Education and Science of the Russian Federation, funds from the foreign sources in the structure of internal costs of research and development in Russia from 2000 to 2012 showed a constant tendency to decrease, being: in $2000-12 \%$; in $2005-7,6 \%$; in $2011-4,3 \%$; in $2012-4,0 \%$.

In this respect, in a short term perspective such a trend of international scientific and technical council as formation and implementation of the projects focused on attraction of foreign investments into the sphere of science and technologies in the short term is to become of great importance.

In this case, that means that expenditures from the foreign sources on carrying out research and development, and direct foreign investments in joint projects for commercialization of the Russian results of intellectual activity.

To complete the picture we will take a closer look at the results of investment and construction activity in the Russian Federation in 2013.

Investments into the fixed capital

In 2013 13255, 5 billion rubles were invested into the fixed capital of the Russian economy (in a full circle of the organizations including the volume of investment unaccounted by the direct statistical methods). In comparison with the corresponding period of the previous year the volume of investment was reduced by $0,2 \%$.

Of the total amount of fixed capital investments (not including small businesses and the volume of investment unaccounted by the direct statistical methods) quite substantial volume of $51,0 \%$ was contributed to the investments into buildings (except residential) and constructions, 35,5\% - to cars, equipment, vehicles (including 16,1\% - imported), $5,8 \%$ - to dwellings, other investments into fixed capital accounted for the remaining 7,7\%. The main financing source for the investments into fixed capital (not including small businesses and the volume of investment unaccounted by the direct statistical methods) were the raised funds of the total share of $53,9 \%$. 46,1\% of investments have been realized at the expense of net worth. The share of all level budgets accounted for 18,8\% against 17,9\% in 2012 of the total amount of investments into the fixed capital.

$84,6 \%$ of investments into the fixed capital fell to the share of the organizations of Russian ownership in 2012 that on 0,5 percentage points is more, than in 2012. The main volume of investment was carried out by the organizations of private form of ownership (45,0\%).

Comparing economic activities by its type we will note that the substantial volume of direct investments into the fixed capital (not including small businesses and the volume of investment unaccounted by the direct statistical methods) is aimed at the development of the following types of economic activity:

- transport and communication $(22,8 \%)$;

- mining (18,9\%);

- manufacturing industry $(17,1 \%)$;

- production and distribution of the electric power, gas and water (11,7\%);

- real estate deeds, rent and services $(9,6 \%)$.

In 201380,2 billion rubles, or $0,8 \%$ of the total amount of investments into the fixed capital, were spent by various organizations (not including small businesses and the volume of investment unaccounted by the direct statistical methods) on construction of environment protection projects. 
In 2013 the expenditures of the organizations (not including small businesses and the volume of investment unaccounted by the direct statistical methods) on acquisition of the fixed assets previously owned by the others legal entities and individuals and objects construction in process accounted for 272,9 billion rubles.

According to the survey of investment activity conducted as of October 10, 2013 in 10,3 thousand organizations specialized in mining, manufacturing industry, production and distribution of the electric power, gas and water, $94 \%$ of the organizations invested into the fixed capital assets (not including small businesses and $42 \%$ - small enterprises (without the microenterprises).

The replacement of obsolete equipment, fixtures and fittings was the main purpose of investment into fixed capital in 2013 , as well as in previous years, as $69 \%$ of respondents pointed out. $39-48 \%$ of the organizations invested for the purpose to increase efficiency of production (automatizing and mechanization of the existing production, launch of new production technologies, decrease of product costs, energy savings). $26 \%$ of the organizations pursued the purposes of the increase of production volumes with invariable product range, and further $34 \%$ - with expansion of product range.

The considerable part of investments into the fixed capital has been allotted for acquisition of machinery and equipment. $87 \%$ of the organizations acquired new machinery and the equipment of the domestic production, $46 \%$ of the organizations - imported products.

On the secondary market the domestic equipment was purchased by $19 \%$ of the organizations, imported - by $8 \%$ correspondingly.

$22 \%$ of the organizations purchased plant and machinery on the terms of financial leasing (in $2012-17 \%$ correspondingly).

In 2013 the principal acquisitions included vehicles, complexes and production lines, separate installations of processing equipment and electronic computer machinery.

Throughout the surveyed organizations the share of plant and machinery under 10 years of service accounted for $39 \%$, over 10 under 20 years - $40 \%$, over 20 under 30 years - 13\% of their length of service. The average life cycle of vehicles is 9 years.

About $60 \%$ of the organizations implemented modernization of fixed assets.

The major factor limiting an investment activity is the lack of net worth. This factor was mentioned by $59 \%$ of heads of the organizations ( 5 percentage points lower, than in 2012). The number of the respondents pointed to low profitability of investments into the fixed capital (from 10\% in 2012 increased to $13 \%$ in 2013), high interest on commercial loan (increased from $25 \%$ in 2012 to $27 \%$ in 2013), insufficient demand for production (from 19\% in 2012 to $21 \%$ in 2013), complicated method of receiving a loan for implementation of investment projects (from 13\% in 2012 to $14 \%$ in 2013) and unsatisfactory condition of inventory (from 7\% in 2012 to $8 \%$ in 2013).

It is worth mentioning that the number of the respondents specified imperfection of the legal and regulatory base regulating investment processes among the factors limiting investment activity, has been reduced (from 11\% in 2012 to 9\% in 2013). In 2014 nearly a half of the chiefs of the organizations are planning to increase the volume of investment into the fixed capital, 31\% - its reduction. In December, 2013 the summary price index of construction production accounted for $100,9 \%$, including a price index of manufacturers in construction (construction and assembly works) $100,6 \%$, on plant and machinery used in construction $-100,0 \%$, for other capital works and expenditures $-107,7 \%$.

\section{Construction activity}

The amount of works realized by the form of business activity named Construction (on a full circle of organizations including amounts of work unaccounted by the direct statistical methods in construction) in 2013accounted for 5917,2 billion rubles, or $98,5 \%$ to the level of the corresponding period of the previous year.

According to the survey of business activity of the construction companies conducted as of November 10, 2013, the index of entrepreneurial confidence in construction for the fourth quarter of 2013 accounted for (-8\%). Positive value of an index of enterpreneurial confidence in the fourth quarter of 2013 was registered in the Republics of Komi, Tatarstan, Dagestan, Stavropol Region, the Moscow, Leningrad, Tyumen areas and St. Petersburg. The lowest value of an index of entrepreneurial confidence $(-37 \%)$ was recorded in the Ivanovo region. The major factors limiting activity of the construction organizations are the following: high taxation rates (pointed by $42 \%$ of the interviewed managers), the competition between civil engineering companies (28\%), insolvency of customers (27\%), high cost of materials, articles, products $(25 \%)$.

The average number of employees involved in construction (on a full circle of the organizations including small businesses) in January-December, 2013 accounted for 2,8 million people and decreased in comparison with the corresponding period of 2012 by $1,2 \%$. 
In January-December 2013 the average nominal monthly salary in construction industry registered at 27, 7 thousand rubles that is 7,2\% above the level of the corresponding period of 2012 and for 7,6\% - below the average all-Russian level.

As of January 1, 201456 construction organizations had arrears on salary. The total debt occurred due to undue funding from the federal and local budgets and the shortage of own means in the construction organizations accounted for 367 million rubles, or $19 \%$ of the total amount of arrears of observed types of economic activity. In comparison with the beginning of 2013 this figure increased by $38,3 \%$, with the last month - decreased by $28,6 \%$. Throughout the enterprises and civil engineering companies having arrears on a salary, its total figure represented the sum equivalent three monthly wages funds.

In 2013 net financial result (profit minus loss) of the construction companies (not including small businesses) in current prices accounted for 121,0 billion rubles (3,4 thousand construction organizations received a profit of 214,7 billion rubles, 1,0 thousand organizations made a loss for the sum of 93,7 billion rubles). In 2013 the share of the unprofitable organizations carrying out construction activity in comparison with 2012 increased by 0,5 percentage points.

Commissioning of construction projects

In 2013254,7 thousand buildings were commissioned (in 2012 correspondingly - 235,2 thousand buildings), with the total structural volume 488,8 million cubic meters (in $2012-447,1$ million cubic meters), and the total area - 112,3 million sq.m (in 2012 - 103,9 million sq.m). Among the projects put into operation in 2013 93,5\% of buildings were residential.

In 2013 912, 1 thousand apartments were built by the organizations of all forms of ownership with the total area of 69,4 $\mathrm{mln}$ sq.m that is $5,6 \%$ higher than during the corresponding period of previous year. Individual developers constructed 30,4 million sq.m of total area of houses, or $43,8 \%$ of the total amount of the housing completed in 2013.The average actual cost of construction of 1 sq.m of total area of detached houses (apartment block type without annexes, superstructures and the built-in rooms, not including the houses constructed by individual developers) in 2013, accounted for 36258 rubles (in 2012 - 34354 rubles).

This level is exceeded by $50 \%$ or more in Chukotka Autonomous Area (80000 rubles), the Magadan region (66909 rubles), the Karachay-Cherkess Republic (64823 rubles), the Sakhalin region (57218 rubles), the Yamalo-Nenets Autonomous Area (56831 rubles) and Khabarovsk Region (54779 rubles). In 56 administrative divisions of the Russian Federation this cost is lower, than the average one across Russia, ranging from the lowest - in the Republic of Dagestan (20746 rubles), Kursk region (22845 rubles) and the Republic of Adige (22995 rubles).

In 2013 in comparison with 2012 construction of educational institutions for secondary professional education decreased by $80,5 \%$, educational institutions for higher education - by $66,8 \%$, theaters - by $65,3 \%$, sanatoria - by $57,1 \%$, recreational centers - by $47,1 \%$, hotels - by $38,1 \%$, cultural clubs - by $28,8 \%$, capacities of the hospital, out-patient and polyclinic organizations - respectively by $26,1 \%$ and $18,3 \%$, shopping centers - by $0,9 \%$; construction of concert and cinema and concert halls almost by 2,0 times, trade and office centers - by 1,5 times, preschool educational institutions - by 1,4 times, educational institutions and nursing homes for elderly and disabled people (adults and children) - by 1,3 times, cult and religious constructions - increased by $4,2 \%$.

In comparison with 2012 commissioning of gas supply pipeline networks decreased by $31,8 \%$, heat supply networks for $26,6 \%$, water supply systems - for $12,6 \%$; commissioning of sewerage networks increased by $3,7 \%$.

In 2013 the following projects for protection of motherhood and the childhood were completed: children's policlinics on 985 patients per shift in the Republics of Ingushetia, Tatarstan, Sakha (Yakutia), Khanty-Mansi Autonomous Area,Ugra, Kemerovo, Moscow, Nizhny Novgorod, Pskov areas; children's hospitals of 319 beds in the Republic of Sakha (Yakutia), Khanty-Mansi Autonomous Area, the Ivanovo, Nizhny Novgorod areas; maternity hospitals of 257 beds in Perm Krai, Irkutsk, Volgograd, Sverdlovsk areas; prenatal clinics in the Republic of Bashkortostan on 100 patients per shift; boarding school for orphan children and children without parental support, for 160 students in PrimorskyKrai. Construction of orphanages and children's homes in 2013 wasn't carried out.

Among the tourist and sport projects o in 2013 are completed the following: tourist centers on 671 beds, motels on 146 beds, camping sites for 122 guests, 41 swimming pools, 30 sport complexes with artificial ice rink of 203,5 thousand sq.m, 114 sport and wellbeing complexes, gyms of 93,3 thousand sq.m, winter sport slopes of 10,0 thousand meters long, the sledge and bobsleigh track of 1,8 thousand meters long.

Buildings. According to the federal targeted investment programme approved by the Ministry for Economic Development of the Russian Federation in 2013 (with amendments as of January 1, 2014), 673,0 billion rubles were allotted, including from the federal budget - 637,5 billion rubles for construction of 2984 capital construction projects, acquisition of real estate property and realization of projects (the integrated investment projects) (further - projects), 
from them for 940 projects only project and development works have been planned.

In 2013 it was planned to put into operation 993 projects. In January-December, 2013346 projects were put into operation, including 288 - at full capacity, 58 objects - partial capacity. For the projects of the targeted investment programme in 2013 from the federal budget 463,4 billion rubles (or $72,7 \%$ of an annual limit) were allotted. From budgets of the administrative divisions of the Russian Federation and other sources 29,2 billion rubles were financed. As of January 1, 20141630 projects are completely financed.

For the beginning of 2014 on 723 projects (not including those on which project and development works for future construction are carried out) technical readiness accounted from $51,0 \%$ to $99,9 \%$ according to the full list of the nomenclature .

Thus, it is obvious that on the one hand investments act as a necessary condition for reproduction mainly, and, as a result, as a basis for strengthening of financial stability and increase of capitalization of the companies. It is also quite important to note that on the other hand the investment system in innovative processes of the company is a key element of investment strategy of development of the construction complex.

So far the main objectives of development of construction companies based on the last years' data could be defined as follows:

- finding the most expedient distribution of investment resources for the maximum increase in company capitalization;

- achievement of the set production outputs with the minimum expenditure of production resources;

- effective production management for the best production management at the minimum expenditures of labor, resources and time;

- development and implementation of the large-scale investment programs for development of the enterprises targeted at modernization and technological re-equipment, diversification of activity and creation of new productions;

-systematic financial implementation of the investment program for development of the enterprises, formation of long-term, economically effective mechanisms of investment in innovative projects.

Taking into account the above-mentioned formulated purposes the main objectives of development of construction companies are the following:

- increase of investment activity of the companies, development of investment potential due to implementation of investment projects and formation of the new objects of investment connected with more science-based and hi-tech production process;

-creation at a regional level of favorable organizational and economic conditions for investment activity of the company;

- improvement of necessary investment infrastructure of the companies;

- development of a range of the modern market tools for attraction of investment resources used by the enterprises and ensuring their effective interaction.

Thus, considering situation in the innovative sphere of construction companies of various regions of Russia, the worsening condition of natural resource base and conditions of business environment, inadequate administrative provision and high level of corruption across the territory, a weak susceptibility to innovations of the Russian business sector, the directions of development of construction companies are as follows:

- stabilization and increase of efficiency of construction business activity;

- assistance to form and introduce effective mechanisms of distribution of new technologies and methods of management on the basis of the realized innovative and investment programs and projects and stimulate competition on the markets of new technologies in construction;

- ensuring sustainable scientific and scientific-technical development of the construction branch, closer and more effective cooperation of the construction enterprises, industrial science and state support of applied research in construction;

- development of interregional and multinational construction companies;

-development of sector of venture business provided coordination of their activity including by the state;

-improvement of search engines and sourcing of material, financial, intellectual and informational resources at implementation of innovative programs and projects;

- application of multicriteria approach at a choice of the best decision. 
The most important problem of management of innovative and investment activity of corporate structure is ensuring balance of its activity.

One of the approaches to the solution of this task is determination of compliance of growth rates of key indicators to the main economic proportions.

$$
\Delta P>\Delta V>\Delta I>\Delta O>\Delta F>\Delta R>
$$

where:

$\Delta \mathrm{P}$ - rate of a gain of profit of the company;

$\Delta \mathrm{V}$ - rate of a gain of revenue;

$\Delta \mathrm{I}$ - rate of a gain of expenses;

$\Delta \mathrm{O}$ - rate of a gain of current assets;

$\Delta \mathrm{F}$ - rate of a gain of fixed assets;

$\Delta \mathrm{R}$ - rate of a gain of number.

For calculation of level of balance of the SBK construction corporation it is possible to use the following formula:

$$
S B_{K}=\left(1-K_{o t k} / S_{o b}\right) * 100 \%
$$

$K_{\text {otk }}$ - quantity of deviations in expression of (1);

$S_{o b}-$ total number of indicators in a linking of indicators of expression of (1).

Depending on number of deviations in expression of (1) various options with assessment of balance may arise. Not considering the weight of indicators in the system of estimates these options will depend only on quantity of deviations in expression of (1). Thus, for example, in a case when one, two, three, four deviations (violation) are observed in the called expression we have the following estimates of balance:

1) If one deviation from five, $S B_{K}=(1-1 / 5) * 100 \%$ of $=80 \%$;

2) If two deviations from five, $S B_{K}=(1-2 / 5) * 100 \%$ of $=60 \%$;

3) If three deviations from five, $S B_{K}=(1-3 / 5) * 100 \%$ of $=40 \%$;

4) If four deviations from five, $S B_{K}=(1-4 / 5) * 100 \%$ of $=20 \%$;

It is obvious that in case of a deviation of all five sheaves balance is equal to zero.

In order to estimate efficiency of investment into creation of new production of the industrial enterprise on the basis of the carried-out analysis it is offered to use the following indicator:

$$
\left.\mathrm{E}_{\mathrm{T}}=\left(\mathrm{A} / \mathrm{A}_{\max }\right) \cdot\left(\mathrm{N} / \mathrm{N}_{\max }\right) \cdot \mathrm{O}_{\mathrm{r}} \cdot \mathrm{SB}_{\mathrm{k}}\right) / \mathrm{I}_{\mathrm{T}-1}
$$

where $\quad \mathrm{E}_{\mathrm{T}}-$ efficiency of investment into creation of new products in the current year $T$;

$A$ - the product range of the considered construction company in the current year;

$A_{\max }$-range greatest possible at the moment or product range of the leader of the market;

$\mathrm{N}$ - product range of the considered construction company in the current year;

$N_{\max }-$ greatest possible list or product range of the leader of the market;

$\mathrm{O}_{\mathrm{r}}-$ a relative share of the market of the considered construction company;

$\mathrm{I}_{\mathrm{T}-1}$ - the volume of investment into creation of innovative production of construction company in the previous year;

$\mathrm{SB}_{\mathrm{K}}$ - balance of key indicators of the company in the current year.

Thus, efficiency of investment into creation of new production of construction company is proposed to estimate relying on relative changes of the product range, variety of nomenclature of production and market capacity of the products occupied by the company against the background of influence of a certain volume of investment into creation of innovative production with delay at least for one calendar year.

In investment strategy of long-term development the main factor of increase of efficiency and competitiveness becomes innovative changes in technology, equipment promoting achievement of economic targets of construction companies. So, mechanization and automation of technological processes will lead to reduction of production costs, duration of construction cycle and production of finished goods.

Task-oriented improvement of technologies, technological processes and introduction of new tools will allow to increase production volume, to reduce construction terms, to improve competitiveness of the company in general and to increase 
profitability of production activity. Use of the energy saving equipment and technologies will allow to improve the use of production capacities, to lower energy consumption and to raise an impact of resources.

Thus, technological innovations represent the final result of innovative activity received an embodiment in the form of the new or advanced technological process or a way of production used in practical activities of construction company.

The main directions of scientific and technical progress in the sphere of design and urban development safety are as follows:

-calculations of difficult models of buildings and constructions taking into account the most dangerous impacts; -technical tests, pilot studies of full-scale designs and projects;

-development of specifications, scientific and technical maintenance and monitoring of design, construction, reconstruction of complex and unique objects and protective structures.

In the sphere of regulation of standardization, assessment and compliance confirmation:

-development of standards for design and introduction in practice of aseismic construction of new methods of research and construction on the basis of seism isolation, damping and other innovative technologies;

-participation in formation of system of inter-branch standardization in the field of town planning, safety and sustainable development of territories;

-activities for assessment and confirmation of compliance, including carrying out technical tests, pilot studies on dynamic stability and seismic stability of construction designs, buildings and constructions.

The priority directions of scientific and technical progress in construction branch are:

-development of information systems and formation of sections of uniform information "Gradoresurs" system with territorial and branch divisions, including information system "Seismic Safety of Russia";

-development of methodical recommendations and author's programs for carrying out pilot studies of front systems and other construction types;

-development of methodical recommendations about identification and a marketing assessment of higher risk territories in the master plan of certain classes of territories;

-techniques and standards according to seismic risk, the rule and the recommendation for certification of objects;

-methodical recommendations, standards and rules for design of buildings and constructions on the basis of innovative decisions and construction technologies without transom frame with application of various type of permanent cast formwork, etc.

The innovative program has to provide conditions for realization of these priority trends. In order to meet the criteria for further development of the enterprises of oil industry will require the corresponding growth of investments with own means as the main sources.

In general research of technological innovations in construction companies show that in the long term perspective the most important of those trends are the following: reliability;

-stage-by-stage reconstruction of the operating processes for the purpose of increase in productivity and

-creation of new technological processes for the purpose of product quality improvement, introduction of energy saving technologies, improvement of production and working conditions safety;

-expansion of the technological capabilities focused on release of hi-tech production of high extent of processing of raw materials for the purpose of compliance of production quality to requirements of perspective standard regulations.

To estimate efficiency of investment into technological re-equipment of construction company, on the basis of the considered direction of researches it is offered to use the following indicator:

$$
\mathrm{ETP}_{\mathrm{T}}=\left(\left(\mathrm{P}_{\mathrm{n}} / 360\right) /\left(\mathrm{P}_{\mathrm{c}} / 360\right) \cdot\left(\mathrm{R}_{\mathrm{n}} / \mathrm{R}_{\mathrm{c}}\right) \cdot \mathrm{SB}_{\mathrm{k}}\right) / \mathrm{ITP}_{\mathrm{T}-1}
$$

where $\mathrm{ETP}_{\mathrm{T}}$ - efficiency of investment into technological re-equipment of construction company;

$T$ - the current parameter of year of calculation of the invested innovative technology in the construction company;

$T P$ - an index of technological re-equipment of construction company;

$P_{n}$ - a temporary assessment of productivity of the invested innovative technology of construction company;

$P c-$ a temporary assessment of productivity on old technology of construction company; 
$R_{n}$-profitability of production made on innovative technology;

$R_{c}$ - profitability of production made on old technology;

$\mathrm{ITP}_{\mathrm{T}-1}$ - the volume of investment into development and development of innovative technologies in the previous

year;

$S B_{K}$ - balance of key indicators of the company current settlement year.

Thus, efficiency of investment into technological re-equipment (modernization) of construction companies is offered to be estimated through changes in the relation of productivity of technologies, and also profitability and the general change of balance of key indicators against the previous target investment into technological re-equipment of the company.

The following direction of investment providing innovations is organizational innovations. It is considered that realization of organizational innovations, as a rule, makes changes to structures of divisions, rendering considerable quantitative and qualitative changes. The essence of organizational innovations consists in search of an optimum combination of the available staffing to the changed norms or working conditions and technological processes.

In this regard for an assessment of efficiency of investment into modernization of organizational structures of the company on the basis of the considered materials the following indicator is offered:

$$
\mathrm{EOI}_{\mathrm{T}}=\left(\left(\mathrm{H}_{\mathrm{n}} / \mathrm{H}_{\mathrm{c}}\right) \cdot\left(\mathrm{P}_{\mathrm{n}} / \mathrm{P}_{\mathrm{c}}\right) \cdot \mathrm{SB}_{\mathrm{k}}\right) / \mathrm{IOI}_{\mathrm{T}-1}
$$

where $\quad \mathrm{EOI}_{\mathrm{T}}-$ efficiency of investment into technological re-equipment of construction company;

$T$ - the current parameter of year of calculation of the invested innovative technology of construction company;

$O I$ - an index of an organizational innovation of construction company;

$H_{n}$ - a number assessment at new organizational structure of construction company;

$\mathrm{H}_{\mathrm{c}}$ - a number assessment at former organizational structure of construction company;

$R_{n}$-profitability of production made at new organizational structure;

$R_{c}$ - profitability of production made at former organizational structure;

$\mathrm{IOI}_{\mathrm{T}-1}-$ the volume of investment into development and development of innovative methods of management in the previous year;

$S B_{K}$ - balance of key indicators of the company current year.

Thus, efficiency of investment into organizational innovations of construction companies is proposed to estimate through changes relative to new staffing of a company, and also profitability and the general change of balance of key indicators against the background of previous target investment into organizational structure and transition to a new format of management in the companies.

As the fourth trend of innovative and investment activity we will consider innovations in development of infrastructure of construction company. It is generally believed that implicitly the infrastructure of the company provides efficiency of innovative and investment projects in the previously considered directions of its use. However, to give the broad assessment of efficiency of creation and development of innovative infrastructure of the companies is quite complicated therefore here we limit ourself to an assessment of its influence on the general profitability of construction company, and also existence of changes at the level of balance of its key indicators.

It will be in that case possible to use the following indicator:

$$
\mathrm{E}_{\mathrm{II}}=\left(\mathrm{P}_{\mathrm{n}} / \mathrm{P}_{\mathrm{c}}\right) \cdot \mathrm{SB}_{\mathrm{k}} / \mathrm{I}_{\mathrm{T}-1}
$$

where $\mathrm{E}_{\mathrm{II}}$ efficiency of investment into infrastructure providing construction company;

$T$ - the current parameter of year of calculation of the construction company invested in infrastructure;

$I I$ - an index of the developed infrastructure innovation of construction company;

$P_{n}$-profitability of production made at new infrastructure providing;

$P_{c}$ - profitability of production made at former infrastructure providing;

$\mathrm{I}_{\mathrm{T}-1}$ - the volume of investment into development and development of innovative methods of management in the previous year;

$S B K$ - balance of key indicators of the company current year. 
Thus, efficiency of investment into marketing innovations of construction companies is offered to be estimated through changes in the relation of profitability and the general change of balance of key indicators against the previous target investment into advances of production and transition to a new format of marketing management into the companies.

$$
\mathrm{E}_{\mathrm{np}}=\left(\mathrm{K}_{\mathrm{n}} / \mathrm{K}_{\mathrm{c}}\right) \cdot\left(\mathrm{P}_{\mathrm{n}} / \mathrm{P}_{\mathrm{c}}\right) \cdot \mathrm{SB}_{\mathrm{k}} / \mathrm{I}_{\mathrm{T}-1}
$$

where $\mathrm{E}_{\mathrm{np}}$ - efficiency of investment into infrastructure providing construction company;

$T$ - the current parameter of year of calculation of the construction company invested in infrastructure;

$n p-$ an index of the new markets of construction company;

$P_{n}$-profitability of production, at an entry into the new markets;

$P_{c}$ - profitability of production made at the former list of sales markets;

$\mathrm{I}_{\mathrm{T}-1}-$ the volume of investment into development and development of innovative methods of management in the previous year;

$S B K$ - balance of key indicators of the company current settlement year.

Thus, efficiency of investment in innovative activity into the new markets of construction companies represents itself a marketing innovation. Therefore we propose to estimate transition to a new format of management of advancement of production of a company through promotion to new sales markets, and also changes in the relation of profitability and the general change of balance of key indicators.

\section{Conclusion}

As a summary of the given particular estimates in the directions of innovative -investment activity it is possible to create the general formula for assessment of efficiency:

$$
\mathrm{E}_{\mathrm{IIn}}=\mathrm{E}_{\mathrm{np}}+\mathrm{E}_{\mathrm{TP}}+\mathrm{E}_{\mathrm{OI}}+\mathrm{E}_{\mathrm{II}}+\mathrm{E}_{\mathrm{Hp}}
$$

We will note that it is possible to continue to experiment with this formula and other formulas given for calculation of efficiency in directions concerning their further deepening and giving of certain weight parameters for their sensible assessment, however, and in this statement they are acceptable for practical use.

Transition of the Russian construction branch to an innovative way of development assumes essential change in mechanisms and structure of economic growth. Scientific and technical progress has to become its main source. The concept of long-term social and economic development of the Russian Federation for the period up to 2020 provides development of Russia in two stages.

The first stage - till 2012 - provides creation of potential for the further growth of economy, in the second stage (2012-2020) - transition to new technological base and only after 2020 innovative and socially oriented growth is to be achieved.

According to the Concept, "the share of the industrial enterprises which are carrying out technological innovations has to increase to $40-50 \%$ (2005 - 9,3\%), the share of innovative production in release of an industrial output - to 25-35\% (2005 $2,5 \%)$ ", "a share of hi-tech sector and economy of knowledge in GDP has to make not less than $17-20 \%$ (2006 - 10,5\%)".

\section{References}

Aniskin, Y. P. (2007). Corporate management of innovative development. Moscow: Omega-L, 411.

Higgins, R. C. (1977). How much growth can a firm afford? Financial Management, 6(3), 7-16. http://dx.doi.org/10.2307/3665251

Investment and construction projects management: International approach, guidance under the editorship of Mazura I.I. Moscow: Omega-L, 2010, 736.

Kaplan, R. S. (1996). The Balanced Scorecard: Translating Strategy into Action. Kaplan R.S., Norton D.P. - Boston (Ma., USA): Harvard Business School Press.

Kasaev, B. S., Razakov A. A. (2013). Marketing aspects of regulating the development of economic systems based on the model for the formation of the structure of GDP. Proceedings of the free economic society of Russia, 179, 39-49.

Klopper, A. (2012). Art economic modeling. M.: Maks press, 648.

Kudrin, A. V. (2012).What do we expect from the new Government. Economic Policy, 2.

Landau, U. V. (2014). Process project management. Paleotip. 112.

Starodubrovskij, I. V. (2012). Where bears us rock events? Economic Policy, 2.

Strategic management. (2010). Ed. by V.p. Nut-M.: MATI, 826.

Tebekin, A.V., \& Kasaev, B. S. (2011). Management of the organizations. Knorus, 434. 
Van Horn, J. K. (2003). The basics of financial management. Moscow: Finances and statistics, 800.

This work is licensed under a Creative Commons Attribution 3.0 License. 